\title{
ALTERNANDO PROFESSORALIDADES NO CAMPO: ENTRE O PASSADO E O PRESENTE, UM ESTAR-SENDO PROFESSOR-MONITOR EM UMA ESCOLA FAMÍLIA AGRÍCOLA
}

\author{
GRASIELA LIMA DE OLIVEIRA ${ }^{1}$ * \\ ORCID: https://orcid.org/0000-0001-9617-8767 \\ ALESSANDRA ALEXANDRE FREIXO ${ }^{2} * *$ \\ ORCID: https://orcid.org/0000-0003-3566-8302
}

\begin{abstract}
RESUMO: Este artigo apresenta narrativas (auto)biográficas de cinco monitores da área de ciências naturais de duas Escolas Famílias Agrícolas (EFA) no semiárido baiano. Por meio de suas memórias e histórias de vida, investigamos o seu tornar-se docente em alternância, referindo-nos tanto à proposta pedagógica da escola, quanto às trajetórias destes docentes, que se alternam entre o passado e o presente, e o estar-sendo professor e o estar-sendo monitor numa EFA. Estas categorias - passado, presente, professor e monitor - se alternam no processo de tornar-se docente no/do campo. Trata-se de uma pesquisa qualitativa, embasada nos referenciaisda memória, (auto)biografia, história de vida e narrativas orais. Para análise das narrativas, nos apropriamos das noções de experiência, de Jorge Larrosa Bondía e de professoralidade, de Marcos Villela Pereira. As narrativas indicam que estes docentes são o que conseguem ser: seres de experiências, contextos históricos, sociais e culturais que os atravessam nesse tornar-se docente numa EFA.
\end{abstract}

Palavras-chave: Pedagogia da Alternância, Ensino de Ciências, Experiência, Professoralidade.

\section{ALTERNATING PROFESSORALITIES IN THE COUNTRY: BETWEEN PAST AND PRESENT, BEING ATEACHER-MONITOR IN AN FAMILY FARM SCHOOL}

\footnotetext{
ABSTRACT: This article presents (auto) biographical narratives of five monitors from natural sciences teaching at two Family Farm Schools in semiarid Bahia state. Through his memories and life stories, we investigate his becoming an alternating teacher, referring both to schools' pedagogical proposals, and teachers' trajectories, alternating between past and present, and being a teacher and being a monitor at a Family Farm School. Categories as past, present, teacher, and monitor, alternate in their becoming a

${ }^{1}$ Universidade Estadual de Feira de Santana (UEFS). Feira de Santana, BA, Brasil

* Mestre em Educação pela Universidade Estadual de Feira de Santana (UEFS). Professora da Educação Básica. Feira de Santana, BA, Brasil. <grasiela_1@yahoo.com.br>

${ }^{2}$ Universidade Estadual de Feira de Santana (UEFS), Programa de Pós-Graduação em Educação (PPGE/UEFS), Feira de Santana, BA, Brasil.

** Professora Titular da Universidade Estadual de Feira de Santana (UEFS). Docente do Programa de Pós-Graduação em Educação (PPGE/UEFS), Feira de Santana, BA, Brasil. <aafreixo@uefs.br> 
teacher in the country. It is a qualitative research, based on memory, (auto) biography, life history and oral narratives as theoretical reference. As a narrative analysis, we appropriated the notions of experience, as defined by Jorge Larrosa Bondía, and professorality, by Marcos Villela Pereira. The narratives indicate that these teachers are what they may be: beings of experiences, historical, social and cultural contexts that maketheir becoming a teacher in a Family Farm School.

Keywords: Pedagogy of Alternation, Science teaching, Experience, Professorality.

\section{ALTERNANDO PROFESORALIDADES EN EL CAMPO: ENTRE EL PASADO Y EL PRESENTE, UN ESTAR- SENDO PROFESOR-MONITOR EN UNA ESCUELA FAMILIA AGRÍCOLA}

RESÚMEN: Este artículo presenta narrativas (auto)biográficas de cinco monitores de ciencias naturales de dos Escuelas Familias Agrícolas (EFA) en el semiárido bahiano. Por medio de sus memorias e historias de vida, investigamos su convertirse en docente en alternancia, refiriéndonos tanto a la propuesta pedagógica de la escuela, como a las trayectorias de estos docentes, que se alternan entre pasado y presente, profesor y monitor. Estas categorías se alternan en el proceso de convertirse en docente del campo. Esta es una investigación cualitativa, basada en los referenciales de la memoria, (auto) biografía, historia de vida y narrativas orales. Para el análisis de las narrativas, nos apropiamos de las nociones de experiencia, de Jorge Larrosa Bondía y de profesoralidad, de Marcos Villela Pereira. Las narrativas indican que estos docentes son lo que consiguen ser: seres de experiencias, contextos históricos, sociales y culturales que los atraviesan en ese convertirse en docente en una EFA.

Palabras clave: Pedagogia da Alternância. Ensino de Ciências. Experiência. Profesoralidad. 


\section{INTRODUÇÃO}

Este artigo é fruto das reflexões desenvolvidas durante os escritos de uma dissertação de Mestrado em Educação, escrita por diversas mãos, que teve como objetivo conhecer a vida em alternância de docentes da área de ciências naturais de Escolas Famílias Agrícolas (EFAs) situadas no semiárido da Bahia. As EFAs são instituições que utilizam o processo educativo para promover a união entre comunidade e escola, diminuindo a dicotomia existente entre conhecimento popular e conhecimento científico, teoria e prática e, desta maneira, proporcionando uma educação de qualidade aos jovens que vivem no meio rural (CAVALCANTE, 2007). O princípio metodológico dessas escolas, a Pedagogia da Alternância, faz o corpo discente alternar entre escola e casa, implicando num processo no qual o educando tem períodos de vivência no meio escolar e períodos no meio familiar (SILVA, 2008), visando uma Educação do Campo, que valorize a vida e o trabalho das pessoas que são do campo.

A Educação do Campo nasce com a luta por reconhecimento da diversidade do povo do campo e a concretização dos direitos sociais, visando romper com a ideia do campo como ambiente de atraso. Essa busca por uma pedagogia do campo surge nas experiências do Movimento dos Trabalhadores Rurais Sem Terra (MST). A todo o momento, nesse clima de tensão, observava-se a real história da desigualdade social no Brasil, sendo os trabalhadores, os que possuíam menor escolaridade. Além do que, questionava-se a grande concentração de terras nas mãos de poucos e as dificuldades para a produção agrícola (SOUZA, 2012).

Sendo a Educação do Campo fruto de diversos movimentos e organizações da sociedade do meio rural, aos poucos vem garantindo a essa população um ensino que se desenvolva no campo. Afinal, as pessoas têm o direito de serem educadas no lugar onde residem, pois a população tem a necessidade de uma educação que valorize sua cultura e que possa contribuir hara a solução de algumas de suas necessidades locais, ou seja, a população rural precisa de uma educação voltada para os sujeitos do campo (CALDART, 2005).

Falar em Educação do Campo é imaginar uma diversidade de experiências educacionais, desde as não formais até as formais. Dentre as diversas experiências formais, centramos nossa pesquisa no contexto de Escolas Famílias Agrícolas do Semiárido Baiano. Nessas escolas, a formação integral é o pilar que caracteriza uma educação para a formação completa da pessoa, a fim de proporcionar o desenvolvimento de cada jovem, por meio de um "tratamento personalizado, através do espírito da iniciativa, criatividade, trabalho de grupo, senso de responsabilidade e de solidariedade, ajudando a construir o Projeto de Vida/Profissional junto com a família e o meio em que vive" (UNEFAB, 2017, p. 2).

Apresentaremos aqui alguns recortes de nossas reflexões em torno das docências que vão se constituindo nessas escolas, tomando como metáfora o processo de alternância, característico da proposta pedagógica das EFAs, extrapolando essas alternâncias para as vidas de professoras e professores que vão se construindo como monitoras e monitores nessas escolas. Enfim, professoras/professores que abraçam alternâncias que extrapolam os limites da escola e percebem, em nossas conversas autobiográficas, suas vidas em um contínuo alternar entre presente e passado, escola e família, campo e cidade... É nesse alternar como processo de construção de professoralidades, que vamos nos debruçar aqui.

Adotamos aqui a noção de professoralidade, considerando que o professor é um sujeito em constante construção, e não um ser fixo ou um modelo a ser seguido, até porque somos seres instáveis. De acordo com Pereira (2016), podemos falar que a professoralidade é vista como um processo de produção de diferença, um estado em risco de desequilíbrio constante. Logo, "vir a ser professor é uma diferença de si que o sujeito produz culturalmente (num campo coletivo), num dos seus inumeráveis movimentos de constituição do mundo" (p. 22).

Nesse processo estão envolvidas as escolhas, feitas por um sujeito que, para Pereira (2016, p. 17) "[...] é um indivíduo que se escolhe e, ao se escolher, escolhe o risco de viver, o risco de vir a ser o que ainda não é, o risco de criar a si mesmo, sem ficar aderido a recortes instantâneos de uma trajetória existencial". As nossas escolhas nos levam a caminhos nem sempre planejados, por isso viver é um risco, o risco de ser o que não se pensava ou de não ser o que se pensava. Com isso, passamos por conflitos, 
deles advém o alternar entre "o que eu sou" e "o que eu quero ser", "o que eu sou" e "o que eu não quero ser".

Retomando nossa metáfora da alternância, localizamos em nossas reflexões um primeiro alternar, nos (re)encontrando com a memória. A memória passa a ser considerada não apenas como um retorno ao passado, mas é também formada na inter-relação entre passado, presente e futuro, podendo ser ressignificada, reconstruída e selecionada (ABRAHÃO, 2009; JESUS, 2000).

Esse alternar da memória, de algum modo, já foi foco de nossas reflexões durante uma pesquisa anterior (OLIVEIRA; FREIXO, 2014), quando percebemos que as histórias de vida dos docentes de uma Escola Família Agrícola são sobremaneira marcadas pela inserção em movimentos sociais do campo, que de algum modo, mesmo que temporariamente, definem uma demarcação entre o ser professor e o ser monitor. E desse alternar da memória emerge outro alternar: entre o estar sendo professor e o estar sendo monitor, no contexto da Pedagogia da Alternância.

Nas EFAs, temos instrumentos didático-pedagógicos que levam o docente a ultrapassar as obrigações de um professor; estes têm a tarefa da sala de aula, preparo de material, mas também precisam acompanhar o/a estudante, no período que estão na escola, do levantar ao deitar, pesquisar e procurar soluções para os problemas do campo. Por isso, Begnami (2003) o compara como um instrutor de automóvel, devendo estar sempre ao lado do/da estudante, e ao mesmo tempo oferecer a autonomia que o/a discente precisa para conduzir o "automóvel".

Ainda assim, existe nas escolas famílias a dicotomia entre o ser professor/a e o ser monitor/a. Ao pesquisar esta questão em uma EFA, percebemos que muito do ser professor e/ou monitor está atrelado à trajetória formativa dos docentes: perceber-se monitor/monitora é ser atravessado por uma história de vida dentro dos movimentos sociais e buscar se formar dentro dos princípios da Educação do Campo; perceber-se professor/a é, de algum modo, ser atravessado pelas vivências disciplinares da sala de aula (OLIVEIRA; FREIXO, 2014). Isto ocorre por sermos seres humanos tocados e afetados por experiências diferenciadas, o que nos leva a constituir nossa professoralidade de acordo com as nossas subjetividades.

As linhas que se seguem são dedicadas, em especial, a esses dois processos de alternar-se nas vidas de docentes no campo: o passado e o presente em alternância, o/a professor/a e o/a monitor/a em alternância. Nesses processos de alternar-se, não estamos em busca de uma identidade docente do campo, mas, inversamente, buscamos um "estar-sendo" docente no campo, inspirando-nos nos escritos de Marcos Vilela Pereira (2016), pelo caráter de provisoriedade que permeiam estas alternâncias.

Neste sentido, Pereira (2016) traz uma reflexão muito importante: para ele não basta perguntar "o que é ser professor/a", pois vai trazer a impressão de que existe uma única forma de ser docente. Devemos questionar "como ser professor/a", para levar em consideração as subjetividades de cada profissional e afirmar que não existe um modelo de ser professor/a.

Toda a reflexão que trazemos aqui sobre estas alternâncias parte das narrativas, das histórias contadas por profissionais que atuam no contexto de escolas do campo. Esses profissionais foram localizados por meio do contato inicial com uma rede de Escolas Famílias Agrícolas atuante no estado da Bahia. A partir de então, buscamos docentes que já possuíam um processo de caminhada nesse universo escolar, de uma média de cinco anos atuando nessas instituições, e que tivessem interesse de participar da presente investigação. Contamos, então, com a participação de quatro monitores e uma monitora, que foram convidados a conversar conosco sobre suas histórias de vida, sobre suas alternâncias nas Escolas Famílias Agrícolas onde atuam.

\section{BIOGRAFIAS, TRAJETÓRIAS E EXPERIÊNCIAS EM ALTERNÂNCIA: CONSIDERAÇÕES SOBRE OS MÉTODOS DA PESQUISA}

Para construir a perspectiva metodológica da presente pesquisa, a apresentação do livro organizado por Meyer e Paraíso (2014) nos auxiliou a observar a importância de as metodologias serem construídas com clareza, porque é por meio delas que se explica como a investigação será desenvolvida, 
os caminhos trilhados durante a sua realização. Independentemente de o caminho ser de estruturas mais ou menos rígidas, ele trará como o estudo foi guiado.

As autoras utilizam a expressão ziguezaguear, mostrando a construção metodológica como um processo constante de vai e vem, "[...] movimentamo-nos ziguezagueando no espaço entre nossos objetos de investigação e aquilo que já foi produzido sobre ele, para aí estranhar, questionar, desconfiar" (MEYER; PARAÍSO, 2014, p. 19, grifo das autoras). Esse ziguezague permite a criação de estruturas que ficam entre aquilo que é tradicional no campo de investigação e o que se busca inventar, experimentar. Pois, o desejo é "renovar e reinventar modos de interrogar" (MEYER; PARAÍSO, 2014, p. 22).

Um ziguezaguear que se aproxima da proposta do alternar dos/das docentes entre um passado, um presente e um futuro. Do passado, lembram o que eram e carregam o que ainda não são; no presente, visualizam o que são, o que desejavam ser e o que querem alcançar no futuro. Esse alternarse é percebido nas suas narrativas, sendo possível visualizar o entrelaçar do passado com o presente e com o futuro; além disso, por meio das suas experiências, conseguem ir e vir no tempo, ziguezagueando em suas narrativas.

Com isso, optamos por adotar uma metodologia que seguisse pelo campo da biografização, utilizando diversos métodos, como narrativas, (auto)biografia, memória, história de vida e entrevista. Diante disso, mergulhamos no universo das abordagens biográficas, que: "[...] caracterizam-se por um compromisso com a história como processo de rememorar, com o qual a vida vai sendo revisitada pelo sujeito. Neste contexto, a memória é algo presente na existência do homem, o que implica numa valiosa importância de seu resgate cuidadoso e ético" (SILVA et al., 2007, p. 27). De acordo com a autora, a história oral, a biografia, a (auto)biografia e a história de vida são métodos enquadrados na metodologia biográfica.

Nas pesquisas (auto)biográficas, os/as participantes podem ser vistos/as como atores/atrizes e também como autores/as, contando histórias que evidenciam o seu percurso formativo. Os trabalhos baseados nesse tipo de pesquisa vêm se consolidando no atual cenário brasileiro em campos de pesquisa e de formação, pois auxiliam aos sujeitos envolvidos a narrarem histórias contribuintes na construção de suas identidades, pessoais e coletivas (SOUZA, 2014).

O uso dos métodos biográficos, na educação, vem ganhando mais importância desde o final da década de 1970. Com o passar dos anos, foi-se percebendo que a (auto)biografia, bem como as histórias de vida, propiciam reflexões sobre a prática docente, sendo, por isso, importante a sua utilização em diversas áreas educacionais, inclusive no processo de formação de professores/as (NÓVOA, 1995).

Essa pesquisa se desenvolveu por meio de textos narrados por quatro monitores e uma monitora de duas Escolas Famílias Agrícolas associadas à Rede de Escolas Famílias Agrícolas Integradas do Semiárido (REFAISA), que contam suas histórias de vidas por meio das entrevistas narrativas. Essas entrevistas não trazem "uma ou a verdade sobre as coisas e os fatos, mas pode-se considerá-las como a instância central que, somada a outras, traz informações fundamentais acerca do vivido e possibilita uma interpretação (mesmo que provisória e parcial) [...]).” (ANDRADE, 2014, p.177, grifos da autora). Pensando no contexto de estudo, acreditamos na possibilidade de as narrativas levarem os/as monitores/as a interpretarem o dia-a-dia escolar, isso por meio do já vivido e do que se pretende viver.

A rede REFAISA surgiu em 1993, com a expectativa de integrar escolas do semiárido baiano que ainda não se encontravam articuladas a nenhuma outra rede de Escolas Famílias, tendo por objetivos: formar jovens aptos a morarem e solucionarem problemas da sua região; disseminar os princípios da Pedagogia da Alternância; proporcionar assistência técnica e pedagógica a estas escolas; e também permitir aos seus docentes e diretores uma formação inicial e continuada. Essa rede reivindica que as políticas públicas deem a devida atenção para a Pedagogia da Alternância, além disso, luta para as EFAs terem o reconhecimento merecido, já que possuem potencial educativo (CAVALCANTE, 2007).

Para o melhor desenrolar das entrevistas, foi elaborado um roteiro de entrevista semiestruturado, por meio do qual os/as monitores/as foram levados a se contarem, recriarem, reviverem as suas histórias. Vale ressaltar que, em virtude de nosso compromisso ético com os narradores, seus nomes não foram identificados, sendo substituídos por sobrenomes fictícios, bem como qualquer menção feita nas narrativas a seus lugares de convívio que pudesse identificá-los foi suprimida. 
As entrevistas foram gravadas, transcritas e enviadas aos participantes para serem lidas e analisadas. Nesse momento, eles tinham total liberdade para acrescentar ou suprimir informações previamente declaradas e, por fim, consentir ou não com o que estava escrito. Esse momento também foi importante para tirar possíveis dúvidas que tenham ficado da escuta dos áudios.

Após esse processo, seguimos com a análise das narrativas (auto)biográficas. Elizeu Clementino de Souza (2014) destaca, dentre as possibilidades de análise, a análise interpretativa e compreensiva. Esse processo analítico se iniciou com a leitura e organização das narrativas a fim de criar um perfil do grupo do ponto de vista individual e coletivo, tendendo a observar singularidades, regularidades e irregularidades das histórias de vida e formação. Após essa análise inicial, foram criadas unidades de análise temáticas, agrupando as narrativas de acordo com as diferenças, as subjetividades e a recorrência (SOUZA, 2014). Para isso, criamos algumas alternâncias para agrupar as narrativas préanalisadas, dentre as quais apresentamos aqui a alternância presente/passado e a alternância professor/ monitor.

A análise em questão é finalizada com a leitura interpretativa e compreensiva das narrativas, que, na realidade, está presente no processo de análise desde o início, quando se realizam leituras e releituras das entrevistas que tenderão a esclarecer questões relacionadas à vida e formação dos envolvidos, aprendizagens adquiridas ao longo de sua história, inclusive as do cotidiano escolar (SOUZA, 2014).

Ao narrar suas histórias de vida, os professores aprendem a refletir sobre si mesmos. A biografia, representada por memórias, narrativas, diários ou imagens, se apresentará de forma que o indivíduo traduza a sua existência, tanto para o outro quanto para si (COSTA, 2012). A pesquisa biográfica é importante como pesquisa e formação, logo, o trabalho biográfico objetiva bem mais do que construir uma trajetória, ele deseja que sujeitos envolvidos reflitam o que realmente sabem sobre a sua pessoa. É claro que esse tipo de pesquisa “[...] permitirá abrir tênues veredas que precisam ser alargadas [...]” (PASSEGGI; SOUZA; VICENTINI, 2011, p. 382).

Buscar a trajetória de vida, pessoal ou profissional, significa entender a vida como uma história. Isso vem se tornando uma importante abordagem metodológica ao trabalhar com saberes, experiências e possibilitar reflexão/conhecimento de si. Os trabalhos com histórias de vida podem ser classificados em dois grupos: "os diversos documentos pessoais (autobiografias, diários, cartas, fotografias e objetos pessoais) e as entrevistas biográficas, que podem ser orais ou escritas" (SOUZA, 2004, p. 141, grifo do autor).

Estas leituras nos levam a compreender que muitos dos textos citados consideram a (auto)biografia conectada com a história de vida, sendo que ambas auxiliam no processo de formação, de repensar e refletir sobre o seu ser docente com base no seu percurso de vida. Contar suas histórias leva esses sujeitos a trazerem suas impressões, suas subjetividades. A opção por descrever as histórias de vida de diferentes sujeitos não significa considerar esses seres como acabados, nem colocar suas histórias como lineares, mas sim a considerar que, por meio da construção e reconstrução dessas histórias, cheias de retrocessos, dificuldades, fazer e refazer-se, iremos socializar impressões, dificuldades e vitórias dos sujeitos que lutam para construir uma Educação do Campo.

Dentro dessa perspectiva, Pereira (2016) afirma que contar história não significa reconstruíla por completo, mas sim apresentar fragmentos que ajudam na composição desse ser, no passado e na atualidade. Enfim, é "[...] tornar evidentes (um pouco, que seja) as entranhas de uma subjetividade, as composições dos meus estados de ser, passados e atual [...]" (PEREIRA, 2016, p. 62).

Com isso, buscamos as subjetividades dos participantes e da participante, por meio das suas narrativas, no entanto, considerando que aquela história não se esgota no caminho que escolheram para narrar a sua vida. As professoralidades que vão se construindo e reconstruindo no percurso de vida indicam instabilidade, estado de alerta, pois estamos em risco de desequilibrar a todo o momento. Sendo assim, as histórias trazidas pelos sujeitos, durante essa investigação, nos mostram como eles estão sendo professores naquele instante; trata-se da sua subjetividade naquele momento, mas em outro momento, ele/a poderá apresentar outras subjetividades, outras biografias, outras memórias.

Concordamos com Pereira (2016), quando ele afirma não desejar postular limites que separem o "que é do que não é", mas sim uma linha provisória que mostre "o tornar-se". Essas ideias 
nos ajudam a pensar que estamos, a todo o momento, nos refazendo. Mais ainda, consideramos que não há um rompimento total com a forma de antes, os momentos de instabilidade proporcionam que um novo ser se reconstrua; no entanto, ele/ela vai ou pode carregar em si, resquícios da antiga forma. Assim, aos poucos, vai construindo a sua professoralidade, pois o/a professor/a deve ser sujeito produtor/a de conhecimentos.

Ao considerar que suas subjetividades interferem no seu fazer e ser profissional, acreditamos que existem diversas nuances nessa condição de ser professor/a, ou, como bem afirma Pereira (2016), podemos falar na professoralidade, que é vista como a diferença entre os sujeitos durante a produção de si.

Essa diferença possibilita a produção de sujeitos da experiência, que precisam tropeçar, serem tombados, mas, caso contrário, se estiverem sempre de pé, alcançarão todos os objetivos propostos e tornam-se incapazes da experiência. Um sujeito da experiência é também "sofredor, padecente, receptivo, aceitante, interpelado, submetido" (LARROSA, 2017, p. 28), por isso, ele tem a capacidade de se formar e transformar.

\section{PASSADO E PRESENTE EM ALTERNÂNCIA: UM ENCONTRO COM OS DOCENTES E OS COMEÇOS/FINS DE SUAS HISTÓRIAS}

Pensamos as narrativas autobiográficas a partir das experiências pessoais ou profissionais, que vão se construindo tomando como base a infância, a vida escolar, a entrada no campo docente, o processo do ser professor/a. Narrativas essas que têm em si o potencial formador por proporcionar a reflexão, importante no entendimento da existência do narrador, dos sentidos atribuídos ao longo do seu processo de formação, dos saberes construídos (SOUZA, 2004), enfim, ajuda o indivíduo a perceber e entender o seu trajeto de vida.

Para iniciar as entrevistas, foi solicitado aos entrevistados para se apresentarem e contarem de onde vieram, suas memórias da infância, em qual contexto social eles/elas iniciaram a sua história vida. Voltar e, no mesmo momento, projetar-se no tempo é importante para refletir sobre o que se está sendo, trazendo, por meio de suas memórias, as marcas da formação:

\footnotetext{
sou[daqui] mesmo, comunidade [...], uma área de fundo de pasto, uma das áreas conquistada através de luta, por conta dessa luta toda que existia, nós tivemos pessoas da comunidade que se inseriram mais cedo nessas discussões (SANTANA, 2017).
}

eu moro na comunidade [...], aqui próximo a escola, fica a um quilômetro. Sou filho de agricultor e comecei a participar na igreja, dos movimentos sociais e foi quando a gente começou a ter a ideia do projeto da escola, administrando a escola, eu venho das pastorais da igreja, catequese, pastoral da CEBs (Comunidade Eclesial de Base) e algumas outras pastorais (BATISTA, 2017).

sou do município [...], nascido e criado na zona rural, então meus pais são agricultores e desde a minha infância até a idade de 26 anos eu moro com meus pais e lido com agricultura, produzindo aquilo que aqui a roça nos permite (ALMEIDA, 2017).

sou filho [daqui] mesmo, da comunidade, sou da zona rural, povoado [...], filho de agricultor, meus pais sempre trabalharam com agricultura, sempre morei na zona rural (MATOS, 2017).

eu sou filha de pequenos agricultores, da comunidade [...] (MOURA, 2017).

Todos/as os/as entrevistados/as são nascidos/as na zona rural e filhos/as de pequenos agricultores, com isso, lidam com a terra desde a infância. O queIsso pode facilitar o fazer escolar, uma vez que o campo demanda currículos que dialoguem com as suas culturas, suas concepções e seus conhecimentos (ARROYO, 2015). Currículos como instrumento para confrontar saberes, como o saber sistematizado (imprescindível na compreensão crítica da realidade) e o saber de classes (provém da comunidade, de acordo com sua forma de sobrevivência). Sendo o saber de classe colocado como ponto de partida no processo de ensino e aprendizagem (SANTOS, 2016). 
Com isso nascer, conhecer e conviver no/com o campo pode facilitar o diálogo entre o saber comum e o científico, sendo um ponto positivo no desenvolvimento das práticas desses/as docentes. Afinal, os/as profissionais das EFAs precisam ser capazes de reconhecer suas potencialidades e as de sua cultura, ao desenvolver uma educação contextualizada que leve em consideração os conteúdos disciplinares, mas também as culturas dos que ali habitam (SANTOS, 2016).

A fala dos/as entrevistados/as, de uma forma geral, remete também à luta e à participação de movimentos em busca da qualidade de vida para o seu povo. Essa luta aparece também na escrita e fala de estudiosos/as e teóricos/as sobre a Educação do Campo, as Escolas Famílias, relatando sempre a importância do movimento para a consolidação desse modelo educacional.

Para cumprir seus objetivos as EFAs vão utilizar os ideais da Pedagogia da Alternância, levando o/a jovem a permanecer alguns dias na escola, em tempo integral, e alguns dias em casa. Desta forma, a alternância é pensada enquanto integração entre escola e família, se organizando em três etapas:, a primeira é de observação e pesquisa (no meio sócio-profissional), a segunda para refletir e aprofundar (no meio escolar) e a terceira, de experimentação e transformação (também no meio sócio-profissional) (UNEFAB, 2017).

Ter uma metodologia de ensino diferenciada demanda docentes com formação específica para aqueles centros, por isso, Arroyo, Caldart e Molina (2011) afirmam que é cada vez mais forte a preocupação a respeito dos processos formativos dos/as educadores/as do campo., Iisso é percebido também nas atitudes de pesquisas e de pessoas responsáveis por formular políticas públicas, sociais e educativas. Os/as profissionais do campo têm suas histórias próprias refletidas no ato educacional, seja nos movimentos sociais, na escola, na família e/ou ainda na luta pela terra.

Essa luta é essencial para fazer o povo do campo ser ouvido, para incomodar aqueles que querem calar e tornar esquecida essa população. É fácil perceber na fala dos/as entrevistados/as o orgulho por terem raízes nessa luta, que começa, geralmente, por parte de um familiar, mas se envolvem a ponto de perceberem a importância de estarem no campo e de serem do campo.

Santana (2017) fala sobre as comunidades de Fundo de Pasto, provindas da ocupação, como elas pregam pelo uso coletivo da terra, seja pública ou do patrimônio comunitário. Portanto, é também uma conquista que o povo do campo alcança por meio da luta. Essa denominação, Fundo de Pasto, surgiu devido as comunidades se localizarem no fundo das casas de moradia, em direção a pastagens livres.

O desejo de lutar por seus direitos, geralmente, começa na infância, pois essas pessoas crescem vendo seus familiares em busca de algo melhor para a comunidade. A fala de Moura (2017) corrobora essa informação:

[...] a minha mãe fazia esse trabalho desde a infância, por isso o meu desejo de estar aqui até hoje, porque na época, antes mesmo de ir para Juazeiro, a minha mãe já era liderança comunitária e aí em todos os momentos do trabalho comunitário eu estava junto da minha mãe, e isso foi me fortalecendo, nesse sentido de um trabalho mais voltado para a classe.

O trabalho comunitário que a mãe fazia despertou na filha o desejo por estar nos movimentos, lutar pelo coletivo, ser solidária, ajudar a sua comunidade. É muito forte na fala da monitora esse envolvimento com os movimentos, culminando na implantação de escolas do campo. A fala dos/as monitores/as que participaram dessa construção, mesmo que indiretamente, refletem a gratidão por terem uma formação voltada para a sua realidade e por poder lutar para o desenvolvimento da sua região.

As especificidades das escolas do campo fazem com que o corpo docente, assim como o corpo discente, precise alternar entre ambiente escolar e ambiente familiar. Aas atribuições extras, que advêm destas diferenças, dão a estes/estas profissionais a denominação específica de monitor/a. No entanto, apesar de os docentes, nesse contexto, serem conhecidos ou se sentirem monitor/a, existe, também ali, a figura e o papel do professor/a. Seja porque alguns não se sentem representados pela figura do monitor/a, ou ainda por sentirem a necessidade, em certas ocasiões, de vestir a roupagem de professor/a. Por percebermos que existe essa alternância entre o ser professor/a e o ser monitor/a, 
decidimos investir na próxima seção para mostrar como e por que ocorre essa alternância no universo das escolas famílias.

\title{
PROFESSOR/A E MONITOR/A EM ALTERNÂNCIA
}

Os quatro monitores e a monitora, narradores nesta pesquisa, têm em comum as raízes no campo, a atuação na área de ciências da natureza e o fato de hoje trabalharem em Escolas Famílias Agrícolas. No entanto, percorreram caminhos diferentes para chegar lá, alguns saíram da EFA com o desejo de voltar para dar continuidade ao projeto, há outros que chegaram por um acaso. Alguns fizeram o curso superior pensando em se especializar para o universo das Escolas Famílias, outros fizeram pelo desejo de estudar.

Relembrar um pouco do percurso dos nossos entrevistados e da nossa entrevistada é importante porque sujeitos com histórias de vida divergentes podem apresentar práticas de acordo com algumas questões próprias de suas trajetórias. Afinal, as lembranças da escola como estudantes tendem a recair sobre o exercício da profissão; ensina-se o que acredita ser melhor para o/a aluno/a, isso de acordo com as aprendizagens e as experiências trazidas da sua posição de estudante, dos conhecimentos e metodologias assimiladas dos/as seus/suas professores/as (TEIXEIRA, 2015). Além disso, pode-se ensinar, também, de acordo com as vivências familiares, os aprendizados que carregam desse momento.

Atualmente, a LDB/1996 aponta para a necessidade do curso superior, em especial a licenciatura, para se atuar na educação básica. No campo, para atenderem às necessidades daquele ambiente, os docentes podem buscar por formações que lhes ajudem a adotar uma metodologia de ensino que atendam às demandas da Pedagogia da Alternância.

Partindo desse pressuposto, adentraremos no universo da formação superior de Almeida, Matos, Moura, Santana e Batista.

\begin{abstract}
Meu primeiro vestibular foi pra letras, também não sei por que eu escolhi letras, não sei o por quê da escolha [...]. O segundo eu já mudei para biologia, era uma área que eu já gostava no ensino médio, aí eu fui e decidi fazer biologia, foi o vestibular que de fato eu passei [...]. Eu fiz o curso de biologia lá e conclui em 2010. Na verdade, biologia não era preferida, porque eu sempre considerei a disciplina como chata, os conteúdos, a forma como eles eram dados, eu não gostava mesmo. Eu comecei a gostar quando uma professora, ela era médica, e começou a trabalhar de uma forma bem mais integrada, a biologia integrada com a saúde. E aí, foi nisso que eu comecei a perceber um pouco, de olhar com mais carinho a disciplina de biologia. Mas era uma disciplina, que sempre eram professores de outras áreas que davam, e aí acho que era essa a dificuldade mesmo. [...] Quando eu fiz o vestibular para biologia, eu não tinha percebido as letras Lic ., eu não sabia que eu iria ser professor, no segundo dia de aula foi que, quando eles apresentaram o curso, eu descobri que de fato eu ia ser professor. Então, não era o meu sonho ser professor, só que depois que eu comecei a fazer a faculdade, alguns professores meus, eles eram muito bons, eu já comecei a olhar com mais carinho a importância de ser professor, e aí eu me apaixonei no decorrer do curso, e hoje eu sou professor porque eu gosto mesmo, não é nem por falta de opção, é por gostar de lecionar mesmo (ALMEIDA, 2017).
\end{abstract}

Na fala de Almeida (2017), o conteudismo da disciplina de biologia, torna-a "chata", geralmente não é conduzida de modo a dialogar com o dia a dia da classe escolar, a justificativa para isso pode ser a falta de profissionais capacitados na área, sobretudo pelo fato de qualquer pessoa acreditar que pode ministrar aulas de biologia. Segundo Ribeiro e Souza (2011), essa é uma questão identificada em muitos centros de ensino, que colocam o ser professor como significado de estar preparado ou ter "aptidão" para ministrar qualquer disciplina do currículo escolar.

Outro aspecto que chama a atenção é a forma como Almeida (2017) descreve o acaso que o levou a ser professor, uma vez que, inicialmente, não se deu conta de que estava entrando em um curso de licenciatura. Logo, ele foi se tornando professor ao longo da sua jornada, o que desmistifica o discurso romântico de ser docente por vocação. Teixeira (2015) aponta que muitos estudos consideram que os/as professores/as se formavam por vocação, no entanto, na atualidade, é perceptível a procura pela profissão por questões financeiras, representadas pela estabilidade e independência profissional. Jesus (2000) também trata dessa questão, ao considerar que é preciso desmistificar o discurso de ser professor/a 
por dom, porque são vários os caminhos que levam um ser humano a essa profissão, inclusive a opção ou não por ela.

As dúvidas e angústias no momento de escolher o caminho a seguir, após terminar o ensino médio, podem ser múltiplas, por isso a sociedade e a família têm grande importância nessa decisão, mas é preciso considerar que, de um lado, escutam-se as vozes exteriores, e do outro, o nosso interior, e desse conflito de opiniões surgem impasses na decisão do que se quer ser. Muitas vezes, a escolha pela licenciatura ocorre mais pela afinidade com a área de conhecimento específica do que com a própria licenciatura, ou seja, "[...] boa parte dos alunos de licenciatura só se dá conta que está fazendo formação para o magistério quando já está dentro do curso. Em geral, sua escolha se deu pela afinidade com a área específica (História ou Biologia, por exemplo).” (PEREIRA, 2016, p. 198-199).

Foi o que aconteceu a Almeida. A escolha do curso por causa da disciplina, não pela licenciatura, e nesse meio tempo, a descoberta de que realmente seria professor. Com relação às lembranças que carrega da sua formação inicial, ele relata que:

A primeira sensação que eu tive na faculdade foi a pior possível, porque primeiro eu esperava um ambiente altamente politizado que você ia revolucionar, e o que encontrei foi um ambiente, meio que elitista, eu não via nada de formação política ali. Foi quando eu percebi que na verdade não era uma universidade com o melhor centro de formação política e que aquele papo de que "sou uma universidade que vou mudar o mundo", eu perdi o encanto na universidade. Era muito comum em meu curso a preocupação com emprego e dinheiro, mas essa formação de mudanças da sociedade eram poucos que tinham esse perfil, [...]. Eu valorizo pela parte do conteúdo mesmo, onde eu tive bons professores claro que a gente sempre acha que poderia ter aproveitado mais, mas a formação política no ambiente da universidade era insuficiente. (ALMEIDA, 2017).

Além do excesso de conteúdo que Almeida (2017) cita ter na biologia do seu ensino médio, a sua formação inicial também trazia a preocupação da matriz curricular com os conteúdos obrigatórios, em detrimento da formação política do corpo discente. O ensino de conteúdos descontextualizados pode fazer com que se perca o estímulo de frequentar uma instituição de ensino, por isso é necessário o diálogo entre o saber escolar e a experiência do educando, o que facilita a aprendizagem e o processo de formação.

Para Teixeira (2015), essa formação conteudista persiste porque os docentes são tidos como técnicos no meio escolar, sendo normal o fato de ter que decorar e memorizar o conteúdo. De forma geral, não se leva em consideração que a formação política, assim como a valorização da experiência dos indivíduos que se envolvem naquele processo, é importante para uma aprendizagem significativa, para uma formação de pessoas capazes de se experimentarem, estando abertos às mudanças.

Pereira (2016, p. 203) considera que "[...] via de regra o caminho das licenciaturas tem muito tormento [...]", isso porque são cursos institucionalizados, presos em "discursos formais, difíceis de entender e, o que é pior, difíceis de relacionar com a prática.". Disso vem o choque durante o processo de formação dos/as professores/as.

Enquanto Almeida (2017) é graduado em biologia, Moura (2017) e Batista (2017) são graduados em pedagogia, mas atuam na área de ciências naturais. Ambos iniciaram a sua vida docente antes de realizarem essa formação inicial.

Sou formado em pedagogia. [...] Formei-me no ensino médio pelo magistério e comecei a trabalhar no município, primeiro com o EJA e só vim dar aula para o ensino fundamental aqui na escola, isso em 2004, quando a escola foi fundada. [...] A minha escolha pelo magistério, foi devido a falta de oportunidade na época, no município só tinha um colégio que oferecia esse curso e os outros cursos que tinham na época não era no município, ficava distante, em Senhor do Bonfim, e ficava mais distante para a gente frequentar as aulas. Foi mais por ter o curso, mas depois que eu comecei a fazer, eu fui gostando. (BATISTA, 2017).

Quando eu cheguei aqui, eu tinha apenas o ensino médio, logo após eu percebi que eu precisava me qualificar melhor enquanto docente, então fiz o curso de pedagogia, logo após assumi a disciplina de artes, depois eu ingressei na pós-graduação, também na mesma universidade da graduação, [...], ela é EaD (MOURA, 2017). 
Nota-se, na fala de Batista (2017), também o acaso do ser professor, a falta de oportunidade para realizar outro curso de formação o levou a fazer o magistério e, logo após, uma graduação na área da docência. Esse não ser professor por vocação corrobora a fala de Jesus (2000) e de Teixeira (2015), apresentadas acima e também foi relatado por Almeida (2017) em sua entrevista. Mas, apesar do estar na profissão por acaso, o gostar e continuar por opção é comum na fala de ambos.

Os outros dois entrevistados, Santana (2017) e Matos (2017), optaram por realizar o curso de formação específica para a Educação do Campo, se especializando nas disciplinas de ciências naturais. Ambos já trabalhavam em uma escola família, realizando assistência técnica e com a necessidade de atuar na sala de aula sentem a falta da formação inicial.

Em 2008 eu fui fazer um curso de Educação do Campo [...], curso superior, o curso de Educação do Campo, logo no primeiro semestre teve o básico, mas depois a gente tinha que afunilar numa área, eu estava me preparando para dar aulas para jovens do campo, mas o quê que eu vou ensinar para eles? [...] E aí o curso se dividiu em duas turmas, era uma turma de 50 estudantes, se dividiu em duas turmas, uma na área de linguagem e outra na área de ciências naturais e da matemática. Como eu já tinha certa afinidade com a área de exatas, de ciências, acabei indo para essa área de ciências. (MATOS, 2017).

Surge a oportunidade desse curso de licenciatura em Educação do Campo, [...], o grupo [...], de pesquisa, que defendeu um pouco isso aí, [...] que pensa muito essa coisa essa perspectiva e sempre dizia para a gente "não adianta a gente ir pra guerra desarmado, se a gente tem uma proposta diferenciada para a sociedade, a gente precisa estar munido de conhecimento, sem conhecimento a gente não consegue dá sustentação a essa proposta". O lema que ela sempre dizia pra gente "estudar, estudar e estudar", inclusive conhecendo o inimigo, conhecendo o outro projeto, para poder a gente se armar e superar. E aí a gente foi, teve uma facilidade, porque como a gente tinha um histórico dentro da Educação do Campo, tinha passagem pelas instituições, congressos, enfim uma série de participação nesses debates, nesse sentido tinha uma vantagem e aí a gente apresentou uma carta e fomos selecionados, aqui da região [...] acredito que foram só três mesmo, e fomos [...] fazer, um desafio, esse curso. (SANTANA, 2017).

A Licenciatura em Educação do Campo é um curso de graduação oferecido por algumas universidades públicas brasileiras. Objetivando formar militantes - educadores com habilidades para atuar nos anos finais do ensino fundamental e no ensino médio da educação básica-, ou seja, agentes de transformação social, comprometidos com a sua escola, sujeitos capazes de lutar e de levar o outro a lutar por seus direitos, valores, cultura. Trata-se de um curso que apresenta o regime de alternância, para que o estudante de graduação possa viver a realidade do campo (MOLINA; SÁ, 2012).

A existência desses cursos é importante porque a formação de professores/as-monitores/as do campo devem avaliar os desafios encontrados no contexto, bem como as necessidades e perspectivas para então constituir educadores/as aptos a pensar uma prática que valorize a realidade do campo e os saberes dessa população. Por isso, formar docentes do campo "[...] envolve muito mais do que o conhecimento dos conteúdos necessários à prática educativa, mas sim, a relação desses com o espaço rural, os saberes, e a forma de vida da população que constrói a sua existência e se constitui enquanto sujeitos de ação." (PACHECO; PIOVESAN, 2014, p. 57).

Como apresentam os entrevistados, Licenciatura em Educação do Campo é um curso que habilita os docentes por área de conhecimento, preparando-os/as ainda para a gestão dos processos educativos escolares e comunitários. Para isso, a matriz curricular desse curso se organiza em quatro áreas de conhecimento: Linguagens - inclui Artes, Literatura e Língua Portuguesa; Ciências Humanas e Sociais; Ciências da Natureza e Matemática; e Ciências Agrárias (MOLINA; SÁ, 2012).

Santana (2017) e Matos (2017) optaram por se aperfeiçoarem na área de Ciências da Natureza e Matemática, os motivos apresentados por eles são bem similares: a carência de docentes na área e a identificação com alguns dos seus mestres do ensino superior. Além da carência de docentes na área, a falta de monitores/as formados para química e física e o papel do curso em Educação do Campo foram imprescindíveis para que Santana e Matos optassem por se habilitarem nessas áreas. Durante o curso, eles tiveram contato com mestres que trouxeram essas disciplinas para as suas realidades, lhes possibilitando ter outro olhar em relação a química e física. 
Esse tipo de formação nos cursos de licenciatura em Educação do Campo nos mostra que eles vêm cumprindo com a sua proposta de um ensino diferenciado, pois esse público precisa de uma formação que valorize o ser humano, reconheça as peculiaridades regionais e possa trazer melhorias para o ambiente (SANTOS, 2016). Enfim, sujeitos que de fato tenham uma formação política, voltada para a sua realidade, que contribuam para se pensar sobre as questões do campo.

Enquanto faziam seus cursos de formação, alguns dos nossos sujeitos precisavam alternar entre o estar na faculdade e o estar lecionando na sala de aula, enquanto outros só tiveram contato com a sala de aula no período do estágio e após a sua formação. Houve, também, a fala a respeito de fazer o curso por uma necessidade pessoal, a fim de obter mais aprendizagem para aplicar no seu contexto de ensino.

Independente do contexto, esses entrevistados e a entrevistada tiveram o seu primeiro contato com o ambiente escolar, com o corpo discente. Algumas narrações descrevem essa experiência como traumática, outras mostram o despreparo, mas outras relatam o prazer de estar naquele ambiente.

O meu primeiro contato com a sala de aula foi no estágio na cidade de Senhor do Bonfim, na sede, principalmente em escolas mais periféricas, onde o poder público não olhava com carinho e a gente sempre encontrava esse sentimento de revolta por parte do alunado, eu trabalhei em turmas normais e também em turmas do EJA. A turma do EJA foi uma turma bem melhor, era uma galera mais madura, isso que me estimulou a ser professor. Quando eu vim para a escola do município, eu fui para essa escola por uma questão política mesmo, era uma escola muito longe da sede, na zona rural, bem no interior mesmo, acho que a pior escola, eles colocaram como algo meio punitivo mesmo. Pior escola com relação a localização e a estrutura, escola que precisa melhorar, é meio que rejeitada pelo poder público e aí quando eu cheguei nessa escola, o meu maior choque foi a forma como a escola pensa educação mesmo, os diretores são colocados por politicagem, a maioria dos professores não são formados, eles são colocados por contrato, havia muita briga, criando um ambiente de guerra, dentro da escola mesmo, e aí os alunos parece que percebem isso, e todo mundo gosta da brincadeira. (ALMEIDA, 2017).

Nas suas primeiras experiências docentes, Almeida (2017) teve contato com escolas carentes de políticas e programas que formassem e informassem aqueles/as jovens. Situação visualizada com frequência nas escolas públicas brasileiras, principalmente nas escolas de periferias, na verdade, esse é um problema antigo. Os governantes não se mostram interessados em formar efetivamente os/as jovens brasileiros/as, as políticas educacionais se vinculam a "[...] disputas partidárias e interesses eleitoreiros que produzem repetida descontinuidade técnica e administrativa gerada pela sistemática destruição, a cada governo, do que foi feito pelos antecessores [...]" (PATTTO, 2007, p. 243-244).

Além dessas questões, enfrentam-se também, no caso específico de Almeida (2017), as incertezas de início de carreira, que contribuem para tornar mais conflitante esse primeiro momento, principalmente devido à falta de experiência. Como afirma Pereira (2016), no nosso processo de construção e reconstrução, existem momentos de estabilidade e instabilidade, o pouso e o voo. O pouso é necessário para conseguirmos nos construir frente ao problema, tentando resolvê-lo, já o voo nos ajuda a perceber novas formas de solucionar o problema. Um tempo curto de carreira faz com que queiramos resolver as questões com base na nossa trajetória, nos nossos mestres, com isso, acabamos não percebendo o ambiente ou as novas pessoas com quem estamos lidando. Disso vem os conflitos, pelos quais Almeida passou - os voos -, mas eles são essenciais também no processo de construção docente.

Cada docente é único, ele/ela torna-se profissional na área a cada dia, a cada decepção, alegria ou turbulência, esse ser professor/a está atrelado às experiências dele/a enquanto pessoa e enquanto profissional, por isso, ser professor é uma profissão que tem em si a instabilidade. Não é possível formar $\mathrm{o} / \mathrm{a}$ professor/a baseado em imagens do passado, como se ele/ela nascesse a partir daquela ideia que tem do ser professor/a, como se já tivesse uma identidade própria. Na realidade, o/a professor/a não nasce, mas sim se constitui a cada momento, durante o desenvolvimento de suas atividades, quando se esforça para ser melhor, para fazer diferente, emergindo, assim, um novo ser, uma nova identidade (QUADROS et al., 2005; TEIXEIRA, 2015).

No dia a dia, cada um de nós vai se construindo. Foi em meio às dificuldades apresentadas que Almeida (2017), Batista (2017), Santana (2017), Moura (2017) e Matos (2017) chegaram ao que são, 
sabendo o que não querem ser. Como afirma Matos (2017), é algo que vai acontecendo "naturalmente, aos poucos", até porque somos sujeitos da experiência e precisamos nos experimentar.

Ter experiência é experimentar, ser tocado, ameaçado, afetado (LARROSA, 2017). Quando falamos do sujeito da experiência enquanto professor/a, podemos relatar que inicialmente reconhecemos que ser professor/a não significa “ter vocação para...", isso já nos ajuda a entender o quão complexa é a profissão e os caminhos que levam a escolha ou não da docência (JESUS, 2000). Como já relatado pelos narradores e pela narradora, ser professor/a envolve uma séria de questões, inclusive o tornar-se que inclui mutações sofridas diante de cada contexto.

Pensando nesse "tornar-se", precisamos saber como foi e está sendo o tornar-se docente nas Escolas Famílias, muitas vezes alternando entre o ser professor/a e o ser monitor/a, algumas entrevistas já mostram suas primeiras experiências docentes nesse contexto, mas outras foram em contextos completamente diferentes. Partindo desse primeiro contato com uma sala de aula das EFAs, enquanto docente, procuramos investigar como foi e vem sendo o processo de seu fazer, desfazer e refazer-se.

Quando eu cheguei aqui eu tinha uma sala aula em que você tem um total domínio, que consegue executar tudo que planeja. Então, isso pra mim foi, o choque que eu tive, foi um choque bom. Entro em uma sala de 45 alunos em que todo mundo me respeita como professor, e vice-versa, então me adaptar aqui foi muito fácil, porque eu vinha de outra realidade, de uma escola abandonada pelo poder público, que não tem cultura pra nada e aí você caí em um ambiente como esse, onde você tem todo um regimento, que ele é cumprido, e ele te dá essa possibilidade de preparar uma boa aula e conseguir dá uma boa aula (ALMEIDA, 2017).

Nota-se, no depoimento de Almeida (2017), o sentir-se confortável com o espaço da Escola Família, por conter regras e normas, além de pessoas aptas a cumprir o que se propõe. Sendo o modelo escolar desejado por ele, lugar com o qual ele está adaptado desde a formação enquanto estudante. Esse é um ambiente que o projeta a ser monitor, o que está atrelado à experiência de adentrar na EFA e perceber outros ritmos, quando compara com as outras escolas onde já atuou. Mas, ao mesmo tempo em que se encontra no universo da sala de aula, esse é o momento de retornar ao professorar, nisso existe o alternar entre o professor e o monitor. O que dificulta o seu trabalho no universo escolar é justamente a proposta pedagógica diferenciada, com a qual ele não possuía aproximação.

[...] essa ainda é uma das dificuldades que a gente ainda tem, primeiro assim porque a gente tem que dá o conteúdo que é programático mesmo, que foi historicamente construído, não pode deixar de dar e para além disso tem que contextualizar, então essa integração, eu não senti dificuldade, eu acho né, talvez eu não seja a melhor pessoa para me auto-avaliar, mas eu não tive muita dificuldade não, em virtude do conhecimento que a gente traz das universidades, que eu acho que nunca é suficiente, mas já é muita coisa. E aí quando você se depara em sala de aula, com um ambiente aqui que você tem para sair e da porta pra fora já é um laboratório, então aí, facilita tudo. (ALMEIDA, 2017).

Almeida (2017) relata sempre o quanto a faculdade foi importante na formação da sua base teórica, facilitando bastante o seu construir professor na EFA, apesar do seu pouco conhecimento dessa metodologia de ensino. O professor que ele carrega em si enfatiza a importância do conteúdo para a formação do corpo discente na EFA. De fato, o conhecimento histórico precisa ser apreendido por toda a humanidade, até porque, sem ele a aprendizagem torna-se frágil, esse conteúdo introduz qualquer sujeito no meio social, político e cultural, não ter conhecimento dele é não enxergar as injustiças que cercam a sociedade e não ter armas para lutar contra esse sistema de dominação (SAVIANI, 2009). Esse conteúdo só não deve ser dado pelo seu valor em si, como ocorre na pedagogia tradicional, mas sim, ele deve falar do e com o sujeito, fazendo-o refletir sobre a sua realidade (FREIRE, 2005).

Apontamos que a preocupação de Almeida (2017), em relação ao conteúdo, ao plano de aula, tem muito a ver com o que ele experimentou enquanto aluno da educação básica e estudante da graduação, o seu saber da experiência, o que lhe aconteceu, leva-o a acreditar que essa é a melhor maneira de se relacionar com aqueles/as meninos/as. Por mais que as Escolas Famílias propagem o discurso que o/a monitor/a deve ter um papel que vai além do cumprimento de conteúdos, devendo ensinar, guiar, 
orientar, aconselhar, acompanhar os/as meninos/as do levantar ao deitar (GIMONET, 2007), Almeida (2017) reconhece essa sua obrigação, mas também não deixa de trazer aquele papel de professor, simplesmente porque ele tem uma forma específica de se pensar, se nomear e se sentir enquanto monitor na EFASE.

Almeida (2017) precisa cumprir com o seu papel de professor, mas também com o papel de monitor, para isso ziguezagueia entre os dois universos. A Escola Família cobra isso dele e o corpo discente também. Ele precisa cumprir os instrumentos didáticos pedagógicos da alternância, o que vem acontecendo com o tempo, com a ajuda do ambiente escolar e também com o apoio de cursos de formação continuada.

Os instrumentos didáticos têm o objetivo de concretizar o projeto da alternância (GIMONET, 2007). Por meio deles, é possível fazer uma relação entre os espaços e tempos formativos, “[...] por possibilitar a interação entre os espaços-tempos formativos, isto é, o tempo-escola e o tempofamília/comunidade [...]" (ARAÚJO, 2013, p. 132). Por isso, a formação em alternância só será significativa se houver envolvimento e comprometimento de todas as pessoas que se integram ao processo, ou seja, os membros escolares, familiares e toda a comunidade. São vários os instrumentos didáticos pedagógicos. Da diversidade de instrumentos pedagógicos, enfatizaremos aqui avaliação da sessão, amplamente citada nas entrevistas, como ressalta Almeida (2017):

Eu tenho qualificado melhor minhas aulas, essa tem sido a maior preocupação, isso porque os alunos eles cobram muito nas avaliações, que tem a avaliação da sessão, no ponto avaliação eles avaliam sempre o monitor, e aí eles cobram que sejam mais dinâmicos, e a gente acaba pegando um pouco dessas avaliações para está melhorando um pouco as aulas. (ALMEIDA, 2017).

A avaliação da sessão é um instrumento didático-pedagógico da Pedagogia da Alternância, sua finalidade é fazer com que os princípios dessa metodologia de ensino sejam concretizados. Com essa avaliação, observa-se como essa proposta pedagógica tem sido desenvolvida e, caso haja necessidade, são propostas algumas mudanças (GIMONET, 2007). Essa avaliação auxilia no refletir e repensar sobre a prática, e a partir dela, o docente pode passar a experimentar outras formas de ser, que surgem da prática e da necessidade de ser diferente, de assumir nova forma, a partir do momento que é possível enxergar a situação por outro ângulo. O excerto de Matos (2017), a seguir, revela esse novo experimentar-se, quando começa a enxergar o corpo discente de outra forma.

Após começar a fazer a licenciatura em Educação do Campo, que eu comecei a, como eu estudava e também ensinava ao mesmo tempo, perceber essa mudança, a gente tinha a disciplina de didática e você também tentava colocar isso em prática aqui e você ia percebendo a reação dos estudantes, eu enquanto estudante, trabalhando com estudantes, você começa um pouco essa diferença, começa a perceber que os meninos não são máquinas, eles são humanos e você precisa saber a forma de lidar, inclusive de lidar com diferentes situações na própria sala de aula. (MATOS, 2017).

Um curso de formação pode, sim, proporcionar a reflexão sobre a sua prática e, a partir de então, levar o sujeito a ter outras atitudes, a construir uma nova identidade, a ir se modificando com o tempo, modificando o seu estar sendo professor/a. A busca de novas formas por Matos (2017), assim como Almeida (2017), retrata que são sujeitos da experiência, por isso capazes de se formar e transformar; ao serem receptivos, estarem abertos ao que é novo, quando são tocados, afetados, por outras situações (LARROSA, 2017).

A percepção de que o corpo discente não é formado por máquinas, para Matos (2017), possibilita-o deixar de ser um mero transmissor de conteúdo e de ver os/as alunos/as como receptores/as de informação. Nesse momento, ele se permite ser tocado por novas experiências, se transformar, ter uma nova identidade, ser diferente, construindo em si a professoralidade (PEREIRA, 2016). As EFAs possuem escolas que, segundo Batista (2017), oferecem diversas ferramentas de trabalho.

Aqui a gente tem mais ferramentas para trabalhar, tem mais oportunidades para acompanhar os estudantes de perto e tem todo um aparato que a gente precisa para trabalhar. Com relação a 
conteúdos, livro didático, além de outras possibilidades, a estrutura da escola já é o melhor instrumento. Os setores de produção são onde podemos fazer uma aula prática de ciências, ou seja, uma aula mais na realidade do campo, os instrumentos ajudam muito a confrontar a realidade do aluno com os conteúdos do livro. (BATISTA, 2017).

Por conta do trabalho diferenciado que os/as docentes do campo precisam realizar, eles/elas são mais conhecidos/as como monitores/as, que precisam acompanhar o desenvolvimento do aluno/a, sendo muito mais do que detentor/a de conhecimento, deve guiar, orientar, ensinar o que for necessário aos/as estudantes e, ao mesmo tempo, ajudar na estruturação dos conhecimentos, sendo um/a facilitador/a de aprendizagens. O/A monitor/a é um/a mediador/a, que caminha lado a lado com o/a seu/sua alternante, exercendo, ao mesmo tempo, funções como, "a educação, a formação, o ensino, a animação" (GIMONET, 2007, p. 148, grifo do autor).

Ser monitor/a exige formação, por isso que ela deve ser contínua, com uma formação pedagógica inicial, que ajudará na introdução e aprendizagem básica do/a monitor/a; a formação para a alternância, dando-lhes base das particularidades que a sua função exigirá; e a formação pela alternância, realizada por equipes educativas da alternância. Essa formação, seja inicial ou continuada, deve "beber na fonte" de conhecimentos que permeiam o ambiente rural (GIMONET, 2007). A falta dessa formação pode trazer para o ambiente das Escolas Famílias apenas a figura do/a professor/a, deixando de lado a do/da monitor/a,

[...] nós já tivemos um tempo que a gente discutiu, até por determinação da REFAISA, que o monitor que não pegou a formação inicial, a formação continuada, que não se dedica o dia a dia, ele vai ser tratado como professor mesmo, porque ele não vai ter condição de fazer essa emenda, desde [...] a comunidade até a escola, passando por alunos, pelos pais. O monitor que só vem dar a aula e volta, ele passa pelo pai e nem dá bom dia, porque não sabe que é pai do aluno. (SANTANA, 2017).

Nos contextos do presente estudo, diz-se que atualmente todos/as os/as profissionais que lá se encontram se sentem no papel de monitor/a, realizando todas as atividades necessárias à alternância.

Só de monitores, eu acredito que são só monitores, tem dois monitores que vem de vez em quando, porque um estuda fora e o outro trabalha, mas eles participam também das reuniões e como hoje o meio de comunicação está bem melhor, e através dele a gente consegue fazer os repasses, o resumo das reuniões, e ele também está inserido em algumas atividades, extra aula, participa da reunião de pais e sabe ir e levar o que está acontecendo, porque quando ele não participa diretamente, ele se informa por meio de um resumo, ou de uma síntese. (SANTANA, 2017).

Essa diferenciação entre professor e monitor aqui a gente não tem tido muito problema, até porque a gente quando entra aqui, ou você aceita ser monitor ou então não tem muito espaço aqui só para ser professor, então já é tudo meio que integral, quando a gente vai pensar o próximo ano, seja no início ou final do ano, todo mundo já entra nas atividades como monitor, não lembro de nenhum caso aqui, que alguém seja só professor, sempre vai ter algumas atividades que vai te forçar a agir como monitor na responsabilidade, como a atividade de retorno ou tantas outras aí. Mas, muitas EFAs têm encontrado esse problema, principalmente quando são cedidos, porque tem a carga horária e aí vai lá da a carga horária e volta. (ALMEIDA, 2017).

Logo quando começamos eram todos monitores, depois foram vindo alguns professores, mas esse ano a gente [...] assim ao longo desse tempo, de 2004 para cá, a gente quase não teve assim a pessoa do professor. A gente teve pouco, mas não superava o monitor, a gente sempre teve uma equipe de monitores que estavam aqui o tempo todo e que até mesmo, esses professores, a gente faz com que ele se torne um monitor. Não que é [tempo para pensar], por que, por exemplo, um professor que tem 20 horas, a gente pede que permaneçam aqui de um dia para outro e nisso eles assumem os instrumentos pedagógicos, as atividades do monitor do dia, para que ele se sinta um monitor também, para não ficar aquela divisão de professor e monitor. Para que todos se sintam monitores. (BATISTA, 2017). 
É notável o domínio da figura do/a monitor/a nessas Escolas Famílias. No entanto, o/a professor/a não é uma figura ausente. Ela está também embutida em uma das atribuições do ser monitor/a; é tão presente que existe a tentativa de diferenciar esses dois sujeitos, que na realidade deveriam ser concebidos como complementares. O/A docente em sala de aula tem em si a figura do/da professor/a, enquanto o/a monitor/a vai predominar fora desse ambiente. Isso fica claro nas narrativas já citadas, em que o/a monitor/a, atua nas atividades extraclasse, geralmente ao desenvolver as atividades dos instrumentos didáticos pedagógicos.

Dessa forma, existe o alternar entre as figuras, ora se é professor/a, ora se é monitor/a. Ficando nesse pingue-pongue, vai e vem, nesse ziguezaguear, o que não significa dizer que, em alguns momentos, não seja preciso ser os dois, ou até muito mais do que os dois. Moura (2017) admite que: “[...] ser monitor não é tarefa fácil, você tem que ser professor, administrador, coordenador, tudo ao mesmo tempo".

Apesar de todas as falas esclarecerem que ambas as figuras permeiam o ambiente destas escolas, Moura consegue ser bem direta em suas palavras. Ser monitor/a, dentre outras atribuições, é também ser professor/a. Logo, não tem como dizer que não existem professores/as na EFA; dentro da sala de aula ele/ela vai estar presente, mesmo naquela pessoa que defende ferozmente ser apenas monitor/a. Ou seja, em algum momento, vai existir a alternância professor/a-monitor/a nos espaços das Escolas Famílias.

No entanto, alguns/as vão se sentir mais confortáveis enquanto professores/as, outros/as como monitores/as. "Mas em sala de aula, é o espaço onde eu me sinto mais confortável, onde você tem um domínio mesmo, e aí você consegue fazer um trabalho muito bom, quando você sai dali, você vira monitor e aí você tem que mudar um pouco, da água para o vinho." (ALMEIDA, 2017).

Podemos atribuir esse sentir-se "mais confortável", enquanto professor, segundo Almeida (2017), pelo simples fato de ele ter sido formado para isso, as suas experiências sempre se voltaram para ser professor. Ele tinha professores/as na educação básica e no ensino superior, o fato de ele não ter tido monitores/as faz com que não se sinta confortável, ou seja, "pronto" para ser monitor, assumir responsabilidades que não são de professor/a, exigindo dele a mudança da "água para o vinho".

No entanto, devido ao seu ambiente de trabalho, é necessário que ele se experimente enquanto monitor, ao exercer funções que ultrapassam o seu fazer em sala de aula e as ideias disciplinares sobre as quais se formou. A alternância exige uma formação política, uma formação contínua, um tornarse, experiência que desestabiliza Almeida, o atravessa, provoca-lhe instabilidade, por isso se sente menos confortável fora do seu ninho: a sala de aula. Para ele, é mais cômodo estar em sala de aula, mas a escola em que atua obriga-o a sair desse ambiente para lidar com os pilares da alternância: educação, família e comunidade. Esse ter que sair da sala de aula, para Almeida, é o que Pereira (2016) considera como tartarugas tendo que sair de ninho para enfrentar muitos obstáculos até chegar ao mar.Nesse percurso, é preciso se despir do que se era e ir ao encontro do que ainda não se é. Ou seja, o ninho de Almeida (2017) é a sala de aula, e sair dela significa construir uma nova figura, nova identidade.eEsse processo não é fácil, podendo deixar marcas irreversíveis, mas traz também um aprendizado imenso.

Moura se sente tão confortável em ser monitora - é o ninho dela - que chega a afirmar: "É uma missão, tem que cumprir aqui, não pode se ausentar por muito tempo" (MOURA, 2017). Ela traz o desejo por trabalhos sociais, esteve no universo EFA e desejou voltar para ele após concluir o ensino médio. Mas, como todo bom profissional, os momentos de crise sempre surgem, e são de extrema importância na formação de um no novo ser, de uma nova identidade.

O ninho de Moura está tão aconchegante que ela se sente muito bem resolvida no quesito de como lidar com a comunidade escolar, se vê na obrigação de contribuir para o desenvolvimento daquele projeto escolar.

Então se o aluno ele estava com alguma dificuldade, meu dever enquanto monitor, é ser muito mais do que um professor, é ser companheiro, amigo, mãe, é ser tudo ao mesmo tempo, por isso que eu faço esse papel de refazer tudo de novo, para que na próxima aula ele já esteja mais motivado e consiga se interar e eu tenho conseguido muitos resultados com isso. (MOURA, 2017). 
É notável o quanto o/a monitor/a tem um papel crucial na alternância, sua função vai além da sala de aula, onde geralmente quem atua é o/a professor/a. O/A monitor/a possui responsabilidades específicas de uma escola do campo, logo, “[...] é concebido como aquele que orienta, motiva, aguça curiosidades, provoca, problematiza, ajuda a construir ou reconstruir conhecimentos, facilita aprendizagens e, quando necessário, também ensina" (BEGNAMI, 2003, p.49).

As palavras de Begnami (2003) reafirmam o que Moura e os outros entrevistados revelam em suas falas: ser monitor/a é muito mais do que professor/a, porque, além de ensinar, ele/a deve orientar os estudantes, ajudar na construção do conhecimento, criar problemas que simulem a vida no campo, dentre outros. Com isso, "[...] o monitor é um animador que acompanha, que vai ao lado como um instrutor de automóvel, mas quem dirige e toma às mãos a responsabilidade pelas aprendizagens é o aluno." (BEGNAMI, 2003, p. 48).

Devido a todas essas singularidades do trabalho docente nas Escolas Famílias, os/as monitores/as possuem uma jornada e um ritmo de trabalho diferenciado. Para executarem todas as atribuições, precisam cumprir uma carga horária mais extensa, inclusive por meio de trabalho voluntário. Almeida (2017) descreve essa rotina diferenciada do ser monitor/a:

Aqui não, a gente já vem com a carga horária e você tem que ter uns 40 por cento é trabalho voluntário mesmo, ou seja, a gente tem aqui, se for calcular a carga horária, a gente tem umas 80 horas, 40 horas são em sala de sala, mas para além da sala de aula tem outras demandas, mas aí é um trabalho voluntariado mesmo, 40 horas para a gente são 4 dias integrais, você entra 05:30 e sai 10 horas, não dá para fazer aquele cálculo que tem uma carga horária para AC, outra de sala de aula (ALMEIDA, 2017).

O/A profissional do campo tem diante de si o desafio de realizar o tempo escola e o tempo comunidade, por meio de um ensino que leve em consideração não apenas os conhecimentos científicos, universais, mas também o contexto e as singularidades daquelas pessoas. Precisam realizar o trabalho de um/a professor/a (planejar, pensar a realidade, preparar atividades, ministrar aulas), mas também precisam ser monitor/a (ficar na escola em tempo integral, fazer trabalhos na comunidade, realizar atividades para além do momento da aula).

\section{ARREMATANDO AS ALTERNÂNCIAS}

Após costurar algumas alternâncias, chega o momento de arrematá-las, mas são arremates com nós frouxos, pois o nosso desejo nunca foi delimitar caminhos, mas sim deixar que cada pessoa seja capaz de se construir, desconstruir e reconstruir. Os nós mal amarrados permitem esse refazer-se no interior de uma vida e de memórias reescritas a cada dia. Aprendemos, ao longo da escrita das narrativas, que todos/as são capazes de se reinventar.

As entrevistas narrativas com os/as docentes das Escolas Famílias Agrícolas nos possibilitaram conhecer um pouco das suas histórias de vida e do seu ser docente atual, e percebemos que de fato a trajetória, a (auto)biografia e a memória podem ser métodos potentes utilizados em cursos de formação, para promover a reflexão profissional, deixando essas pessoas abertas a outras experiências, a fazer e refazer a sua prática sempre que possível, não tendo vergonha de tentar, ter que errar ou acertar.

Retomamos aqui o objetivo deste estudo, em que se tinha o desejo de conhecer a vida em alternância dos monitores/as da área de ciências naturais na EFA, enfim, a construção do seu ser e tornar-se profissional da educação do/no campo, com base nas suas trajetórias/histórias de vida. Para isso, consideramos as suas memórias em construção. Nelas, presente, passado e futuro se entrelaçam de forma que não é possível delimitar quando um começa ou termina e, assim, um vai interferindo na construção do outro.

Nas escolas do campo também existe o tempo da colheita, do plantio e da escola, daí aparece como desafio a necessidade de se construírem centros educacionais que dialoguem com essa realidade. Escolas urbanocêntricas, geralmente, não atendem a essas demandas, por isso as entrevistas mostram a luta pela construção das Escolas Famílias. Escolas que estão e são do campo, mas que precisam dialogar 
com o modo de vida urbano, até porque é muito comum no campo o vai e vem desse ambiente para a cidade e vice-versa.

$\mathrm{Na}$ EFA, os/as docentes são conhecidos por monitores/as, no entanto, pode-se perceber que a figura do/da professor/a ainda é forte, como se vê na fala de Almeida (2017), que se sente mais confortável como professor do que monitor. Na realidade, o/a monitor/a tem responsabilidades para além daquelas do/a professor/a, como apresentado anteriormente. Ele/ela precisa trabalhar de acordo com os ideias da Educação do Campo, das EFAs, da Pedagogia da Alternância, precisa dormir na escola, atuar por vezes como responsável pelo estudante, atuar na formação científica, pessoal, profissional, humana, política... mas isso não significa dizer que a figura do/a professor/a está ausente, até porque a sala de aula ainda é domínio do/a professor/a; já fora dela, prevalece o/a monitor/a. Por isso, existe um alternar constante nessas escolas entre o ser professor/a e o ser monitor/a.

Para alguns/mas, 'vestir-se' de monitor/a é mais confortável, enquanto outros/as preferem ser professor/a. Muito do sentir-se como monitor/a ou professor/a está ligado à história/trajetória desses sujeitos, principalmente, se tiveram sua história de vida atravessada pela experiência em movimentos sociais, como estudantes numa EFA ou a depender de sua formação inicial e continuada no contexto da Pedagogia da Alternância. Esses são os principais elementos que levam Santana (2017), Batista (2017), Matos (2017) e Moura (2017) a construir seu ninho no universo do monitor/a.

Mas nem todos os ninhos, na EFA, são construídos no universo do monitor/a. Há docentes que constroem ninhos no contexto do ser professor/a, como Almeida (2017). Isso também é uma construção histórica, baseada em sua formação na infância, educação básica e na formação inicial e continuada.

Porém, independente de onde o ninho foi construído, o mais importante é permitir-se voar e olhar, enxergar o mar, adentrar nele e observar as suas incertezas, os medos, as fissuras e, assim, permitir-se mudar, ser tocado, afetado por novas experiências, por fim projetar um novo ser. Esse projetar-se ao novo ajuda na construção do/a docente cheio/a de multiplicidades, sendo autor/a do ensino e enxergando o corpo discente também como autores/as.

Ser sujeito no processo de ensino significa levar em consideração as singularidades de todos/todas os/as envolvidos/as no processo, construindo a professoralidade, o/a docente que se consegue ser. Os relatos dos monitores e da monitora que participaram desta pesquisa mostram que ela e eles são o que conseguem, trazendo suas angústias para chegar ao seu momento atual. São seres com experiências, preservadas nas memórias, contextos históricos, sociais e culturais que os atravessam e levam-nos/as a esse tornar-se, conseguir ser. "O ser professor por acaso" lhes possibilita seguir trilhas diferentes da que haviam projetado.

São profissionais que se percebem mudando a sua maneira de ser docente ao longo dos anos, para poder cumprir os instrumentos didático-pedagógicos da Pedagogia da Alternância; esse reconstruirse afirma a impossibilidade de apresentarem uma identidade fixa, mas sim identidades que vão se desconfigurando e reconfigurando, a cada momento de instabilidade, a cada oportunidade de mudança.

\section{REFERÊNCIAS (CAIXA ALTA, NEGRITO, CALIBRI 12, ALINHADO A ESQUERDA)}

ABRAHÃO, Maria H. M. B. O método autobiográfico como produtor de sentidos: a invenção de si. Revista Actualidades Pedagógicas, n. 54, p. 13-28, Jul.-dez. 2009. Disponível em:

<https://revistas.lasalle.edu.co/index.php/ap/article/view/947/854>. Acesso em: 27 jul. 2016.

ALMEIDA, Diogo. Entrevista III. [Abril 2017]. 1 arquivo .mp3 (57 min.).

ANDRADE, Sandra dos S. A entrevista Narrativa ressignificada nas pesquisas educacionais pósestruturalistas. In: MEYER, Dagmar E; PARAÍSO, Marlucy A. Metodologias de pesquisas póscríticas em educação. 2. ed. Belo Horizonte: Mazza Edições, 2014. p. 175-195. 
ARAÚJO, Sandra R. M. de. Formação de educadores do campo: um estudo sobre a experiência de formação inicial para os monitores das Escolas Famílias Agrícolas do estado da Bahia. 2013. 317 f. Tese (Doutorado em Educação e Contemporaneidade) - Universidade do Estado da Bahia, Programa de Pós-Graduação em Educação e Contemporaneidade, Salvador, Bahia, 2013.

ARROYO, Miguel G. Os Movimentos Sociais e a construção de outros currículos. Educar em Revista, Curitiba, Brasil, n. 55, p. 47-68, jan./mar. 2015. Editora UFPR. Disponível em: <http://www.scielo.br/pdf/er/n55/0101-4358-er-55-00047.pdf >. Acesso em: 16 jan. 2017.

ARROYO, Miguel G.; CALDART, Roseli S.; MOLINA, Mônica C. Apresentação. In: (Orgs.).

Por uma Educação do Campo. Petrópolis, Rio de Janeiro: Vozes. 2011. p. 7-18.

BATISTA, Eduardo. Entrevista II. [Abril 2017]. 1 arquivo .mp3 (65 min.).

BEGNAMI, João B. Formação pedagógica de monitores das escolas famílias agrícolas e alternâncias: um estudo intensivo dos processos formativos de cinco monitores. 2003. Dissertação (Mestrado) - Faculdade de Ciências e Tecnologia, Universidade Nova de Lisboa, Minas Gerais, 2003.

BRASIL. Lei de Diretrizes e Bases. Lei no 9.394/96, de 20 de dezembro de 1996. Disponível em: < http://www.planalto.gov.br/ccivil_03/leis/19394.htm>. Acesso em: 29mai. 2020.

CALDART, Roseli S. Por uma educação do campo: traços de uma identidade em construção. In: ARroyo, M. G; CALBARTE, R. S; MOLINA, M. S. Por uma educação do campo. Petrópolis, RJ: Vozes, 2005.

CAVALCANTE, Ludmila O. H. A escola família agrícola do sertão: entre os percursos sociais, trajetórias pessoais e implicações ambientais. Tese (Doutorado em Educação) - Faculdade de Educação, Universidade Federal da Bahia, Salvador, 2007.

COSTA, Silvano S. O. Caminhos para o conhecimento de si: narrativas auto(biográficas) na formação inicial/continuada de professores. In: VI Colóquio Internacional "Educação e Contemporaneidade", 2012, São Cristovão, SE. Anais eletrônicos. Disponível em:

<http://educonse.com.br/2012/eixo_04/PDF/51.pdf>. Acesso em: 14 abr. 2016.

FREIRE, Paulo. Pedagogia do oprimido:[texto integral]. Rio de Janeiro: Nova Fronteira, 2005.

GIMONET, Jean-Claude. Praticar e compreender a Pedagogia da Alternância dos CEFFAs. Petrópolis, RJ: Vozes, Paris: AIMFR - Associação Internacional dos Movimentos Familiares de Formação Rural, 2007.

JESUS, Regina de F. de. Sobre alguns caminhos trilhados... ou mares navegados... Hoje, sou professora. In: VASCONCELOS, Geni Amélia Nader (Org.). Como me fiz professora. Rio de Janeiro: DP\&A, 2000. p. 21-41.

LARROSA, Jorge. Tremores: escritos sobre a experiência. Tradução de Cristina Antunes, João Wanderley Geraldi. 1. ed.; 3. reimp. Belo Horizonte: Autêntica Editora, 2017. 175 p. (Coleção Educação: Experiência e Sentido).

MATOS, Ronaldo. Entrevista IV. [Abril 2017]. 1 arquivo .mp3 (83 min.).

MEYER, Dagmar E.; PARAÍSO, Marlucy A. Metodologias de pesquisas pós-críticas ou sobre como fazemos nossas investigações. In: . Metodologias de pesquisas pós-críticas em educação. 2. ed. Belo Horizonte: Mazza Edições, 2014. p. 17-24.

MOLINA, Mônica C.; SÁ, Lais M. Licenciatura em Educação do Campo. In: CALDART,Roseli S.; PEREIRA, Isabel B.; ALENTEJANO, Paulo; FRIGOTTO, Gaudêncio (Org.). Dicionário da 
Educação do Campo. Rio de Janeiro: Escola Politécnica de Saúde Joaquim Venâncio; São Paulo: Expressão popular, 2012.

MOURA, Ednalva. Entrevista V. [Abril 2017]. 1 arquivo .mp3 (61 min.).

NÓVOA, António. Os professores e as histórias da sua vida. In: NÓVOA, António (Org.). Vida de professores. 2. ed. Porto, Portugal: Porto editora. 1995. 214 p.

OLIVEIRA, Grasiela L. de; FREIXO, Alessandra A. Percepções da docência em uma Escola Família Agrícola do Semiárido Baiano: subsídios para o ensino de ciências no contexto da educação do campo. Atos de pesquisa em educação - PPGE/ME, v. 9, n.1, p. 186-213, 2014. Disponível em: $<$ https://proxy.furb.br/ojs/index.php/atosdepesquisa/article/view/3601/2643>. Acesso em: 29mai. 2020.

PACHECO, Luci M. D.; PIOVESAN, Juliane. Educação do Campo: desafios e perspectivas para a formação docente. Revista de Ciências Humanas, v. 15, n. 24, p. 47-59, 2014. Disponível em: <revistas.fw.uri.br/index.php/revistadech/article/view/1378/1726>. Acesso em: 16 nov. 2016.

PASSEGGI, Maria da C.; SOUZA, Elizeu C. de;VICENTINI, Paula P.Entre a vida e a formação: pesquisa (auto)biográfica, docência e profissionalização. Educação em Revista, Belo Horizonte, MG, v. 27, n.01, p. 369-386, abr. 2011. Disponível em: <www.scielo.br/pdf/edur >. Acesso em: 23 ago. 2016.

PATTO, Maria Helena S. "Escolas cheias, cadeias vazias": Nota sobre as raízes ideológicas do pensamento educacional brasileiro. Estudos avançados, São Paulo, v. 21, n.61, 2007. Disponível em: < www.scielo.br/pdf/ea/v21n61/a16v2161.pdf>. Acesso em: 08 jun. 2017.

PEREIRA, Marcos V. Estética da professoralidade: um estudo crítico sobre a formação do professor. Santa Maria: Ed. Da UFSM, 2016. 245 p.

QUADROS, Ana L. de et. al. Os professores que tivemos e a formação da nossa identidade como docentes: um encontro com nossa memória. Ens. Pesqui. Educ. Ciênc.,v. 7 n. 1, Belo Horizonte, 2005. Disponível em: <www.scielo.br/pdf/epec/v7n1/1983-2117-epec-7-01-00004.pdf>. Acesso em: 17 jun. 2017.

RIBEIRO, Neurilene M.; SOUZA, Elizeu C. de. Vidas de professoras de escolas rurais:memórias da manhã, tarde e noite. Revista Pedagógica - UNOCHAPECÓ, Chapeco, SC,v. 13, n. 27, p. 115-140, jul./dez. 2011. Disponível em: <https://bell.unochapeco.edu.br /revistas/index.php/pedagogica/article/view/1302/716>. Acesso em: 27 jul. 2016.

SANTOS, Juarez Severino dos. Entre o campo e a cidade:relações e concepções dos docentes acerca dos sujeitos aprendentes da escola do campo. 2016. Dissertação (Mestrado em Ciências da Educação) Escola Superior de Educação Almeida Garrett, Lisboa, 2016.

SANTANA, André. Entrevista I. [Abril 2017]. 1 arquivo .mp3 (70 min.).

SAVIANI, Dermeval. Escola e Democracia. Campinas, SP: Autores Associados, 2009.

SILVA, Aline P. et al. "Conte-me sua história": reflexões sobre o método de História de Vida.

Mosaico: estudos em psicologia, Belo Horizonte, v. I, n. 1, p. 25-35, 2007. Disponível em: <seer.ufmg.br/index.php/mosaico/article/view/4344/3154>. Acesso em: 18 out. 2016.

SILVA, Lourdes H. da. Educação do Campo e Pedagogia da Alternância: a experiência brasileira. Sísifo, Revista de ciências da educação, n. 5, jan/abr 2008. 
SOUZA, Elizeu C. de. Diálogos cruzados sobre pesquisa (auto)biográfica: análise compreensivainterpretativa e política de sentido. Educação - Revista, Santa Maria, v. 39, n. 1, p. 39-50, jan./abr. 2014. Disponível em: < periodicos.ufsm.br/reveducacao/article/view/11344/pdf>. Acesso em: 27 jul. 2016.

. O conhecimento de si: narrativas do itinerário escolar e formação de professores. 2004. 344 f. Tese (Doutorado em Educação) - Faculdade de Educação, Universidade Federal da Bahia, Salvador, 2004.

SOUZA, Maria A. Educação do Campo, desigualdades sociais e educacionais. Educ. Soc., Campinas, v. 33, n. 120, p. 745-763, 2012. Disponível em: <www.scielo.br/pdf/es/v33n120 /06.pdf>. Acesso em: 30 mar. 2017.

TEIXEIRA, Maria S. da S. Histórias de vida de professoras de Ciências Biológicas em

Guanambi - Bahia. 2015. 297 f. Dissertação (Mestrado em Educação Científica e Formação de

Professores) - Universidade Estadual do Sudoeste da Bahia, Jequié, BA, 2015.

UNEFAB. Histórico. Orizona, Goiás, 2017. Disponível em:

<www.unefab.org.br/p/historico.html\#.WTWUkJLyvMw>. Acesso em: 04 ab. 2017.

Submetido: $05 / 12 / 2018$

Aprovado: $17 / 08 / 2020$ 